\title{
GERAK LURUS BERBASIS ARDUINO UNO: ALAT PERAGA FISIKA ALTERNATIF MENGGUNAKAN LINEAR AIR TRACK
}

\section{LINEAR MOTION BASE ON ARDUINO UNO: ALTERNATIVE PHYSICS TEACHING AID WITH LINEAR AIR TRACK}

\author{
Istiqomah $^{1}$, Yusro Al Hakim ${ }^{*}$, Eko Setyadi Kurniawan ${ }^{2}$ \\ ${ }^{1,2,3}$ Program Studi Pendidikan Fisika, Fakultas FKIP Universitas Muhammadiyah Purworejo, Indonesia \\ *Email: istitiefa@gmail.com
}

Diterima: 14 September 2020. Disetujui: 17 Oktober 2020. Dipublikasikan: 30 Desember 2020

\begin{abstract}
Abstrak: Telah dikembangkan alat peraga fisika gerak lurus dengan linear air track berbasis Arduino Uno untuk mengetahui: (1) tingkat akurasi alat peraga (2) validitas alat peraga, dan (3) kepraktisan alat peraga. Penelitian ini dilakukan diprogram studi Pendidikan Fisika Universitas Muhammadiyah Purworejo. Penelitian ini mengadaptasi model pengembangan ADDIE (Analysis Design Develop Implement Evaluation). Teknik analisis menggunakan analisis uji coba alat, data instrumen validasi, data angket respon mahasiswa dan keterlaksanaan pembelajaran serta hasil percobaan. Berdasarkan uji coba alat yang dilakukan dengan penghitungan waktu secara manual dan menggunakan sensor diperoleh selisih nilai rerata sebesar $0,008 \mathrm{~s}$. Berdasarkan analisis hasil validasi diperoleh skor rata-rata 3,14 dengan persentase $86,33 \%$ (kategori sangat baik). Hasil analisis keterlaksanaan pembelajaran pada aspek pendahuluan diperoleh nilai rerata sebesar 16,00, aspek kegiatan inti 26,00 dan aspek penutup senilai 16,00. Ketiga aspek tersebut diperoleh rerata skor sebesar 3,75 dengan kategori sangat baik. Berdasarkan analisis tersebut dapat disimpulkan bahwa penelitian pengembangan ini menghasilkan media pembelajaran berupa alat peraga gerak lurus dengan linear air track berbasis Arduino Uno untuk menghitung waktu benda saat melintas dengan tingkat akurasi dan validitas yang baik serta alat peraga praktis digunakan untuk pembelajaran.
\end{abstract}

Kata Kunci :Alat Peraga, Arduino Uno, Linear Air Track

\begin{abstract}
Alternative physics teaching aid with linear air track based on Arduino Uno have been developed to determine: (1) the accuracy of the teaching aid (2) the validity of the teaching aid, and (3) the practicality of the teaching aid. This research was conducted in the Physics Education study program, Muhammadiyah University of Purworejo. This research adapts the ADDIE (Analysis Design Develop Implement Evaluation) development model. The analysis technique uses a trial analysis tool, validation instrument data, student response questionnaire data and the implementation of learning and experimental results. Based on the trial of the tool carried out by calculating the time manually and using a sensor, the difference in mean value is $0.008 \mathrm{~s}$. Based on the analysis of the validation results, it was obtained an average score of 3.14 with a percentage of $86.33 \%$ (very good category). The results of the analysis of the implementation of learning in the preliminary aspects obtained a mean value of 16.00 , the core activity aspects were 26.00 and the closing aspects were 16.00. These three aspects obtained an average score of 3.75 in the very good category. Based on this analysis, it can be concluded that this development research produces learning media in the form of teaching aid for straight motion with a linear air track based on Arduino Uno to calculate the time of objects as they pass with good accuracy and validity and practical teaching aid used for learning.
\end{abstract}

Keywords :Teaching Aid, Arduino Uno, Linear Air Track

\section{PENDAHULUAN}

Belajar mengajar merupakan proses penyampaian pesan dari sumber pesan melalui media tertentu ke penerima pesan. Sumber pesan, media dan penerima pesan merupakan komponen dari proses komunikasi [1]. Kegiatan pembelajaran dapat dibantu menggunakan media pembelajaran yang mampu meningkatkan motivasi dan prestasi peserta didik, selain itu media pembelajaran juga dapat memperjelas pesan supaya tidak terlalu verbalitas dalam mengatasi keterbatasan ruang, waktu, tenaga, dan daya indra serta membantu peserta didik belajar sesuai bakat, kemampuan, visual, auditori, dan kinestetik sehingga dapat memberikan rangsangan dan persepsi yang sama [2]. Alat peraga merupakan salah satu media yang dapat digunakan untuk melatih keterampilan proses sains dan sikap ilmiah siswa. Penggunaan alat peraga dapat memvisualisasikan fenomena abstrak menjadi lebih jelas dan mudah dipahami [3].

Alat peraga dikatakan layak digunakan apabilatelah memenuhi criteria kelayakan yang meliputi validitas, efektifitas dan praktibilitas [4]. Alat peraga dikatakan valid apabiladi dalamnya memuat pencapaian tertinggi dari permasalahan yang akan diselesaikan serta semua komponen dalam alat peraga harus berhubungan antara satu dengan yang lainnya, sedangkan alat peraga dikatakan 
praktisapabila alat peraga mudah digunakan dan alat peraga dikatakan efektif apabilahasil pembelajaran siswa setelah mengikuti kegiatan pembelajaran meningkat dan lebih baik setelah menggunakan alat peraga tersebut [5].

Alat peraga yang dibutuhkan siswa untuk memahami konsep dan mengeksplor kemampuan siswa di era revolusi industri 4.0 perlu adanya inovasi alat peraga yang praktis yang menggunakan alat control, seperti perangkat atau sensor detector, LCD, dan mikrokontroler. hal tersebut untuk mengurangi ketidakakuratan dalam pengukuran dan efisiensi [6]. Pemanfaatan alat peraga pembelajaran berbasis mikrokontroler menghasilkan keefektifan pembelajaran dan meningkatkan motivasi belajar siswa [7]. Alat eksperimen berbasis teknologi juga dapat meningkatkan pemahaman siswa terhadap materi yang dipelajari dengan hasil pembelajaran yang baik [8]

Berdasarkan penelitian terdahulu yang berjudul Pembuatan Air Track untuk Eksperimen Kinematika dan Dinamika Berbasis Mikrokontroler ATMEGA328. Berdasarkan hasil pengukuran yang telah diperoleh, data sedikit berbeda dengan pengukuran menggunakan alat standar. Perbedaan tersebut karena pada bagian elektronika sistem memiliki delay program sehingga terjadi delay penghitungan waktu. Alat peraga ini menggunakan 2 sensor photogate, sensor 1 berfungsi untuk menghidupkan timer 1 dan jarak, sedangkan timer 2 digunakan untuk menghidupkan timer 2 dan mematikan timer jarak [9].

Berdasarkan hasil observasi di laboratorium universitas muhammadiyah purworejo diperoleh informasi bahwa alat peraga gerak lurus masih menggunakan ticker timer dan penghitungan manual, sedangkan berdasarkan hasil wawancara oleh dosen mata kuliah fisika dasar 1 diperoleh informasi bahwa terdapat beberapa mahasiswa yang kurang aktif dan antusias dalam kegiatan pembelajaran. Hasil analisis kebutuhan siswa diperoleh informasi bahwa mahasiswa lebih senang dan tertarik apabila pembelajaran materi gerak lurus menggunakan alat peraga yang inovatif serta berbasis digital.

Berdasarkan paparan di atas peneliti tertarik untuk mengembangkan alat peraga gerak lurus dengan menggunakan linear air track berbasis Arduino Uno. Air track merupakan sebuah alat yang menyediakan lintasan lurus dan menggunakan udara untuk meminimalisasikan gesekan sehingga tingkat kestabilan gerak benda yang berjalan di sepanjang lintasan memiliki tingkat akurasi yang lebih baik. Alat peragagerak lurus ini dilengkapi dengan sensor infrared sejumlah 6 sensor untuk menghitung waktu benda yang melintas pada air track.

\section{METODE PENELITIAN}

Penelitian ini dilakukan di Universitas Muhammadiyah Purworejo Program Studi Pendidikan Fisika semester VIII seju,lah 11 orang yang dilaksanakan pada semester genap tahun akademik 2019/2020. Penelitian ini mengadaptasi model pengembangan ADDIE (Analysis Design Develop Implement Evaluation). Implementasi model ADDIE secara sistematik dan sistemik akan menjamin terciptanya sebuah program pembelajaran yang efektif dan efisien [10]. Tahapan-tahapan penelitian dan pengembangan ditunjukkan pada Gambar 1.

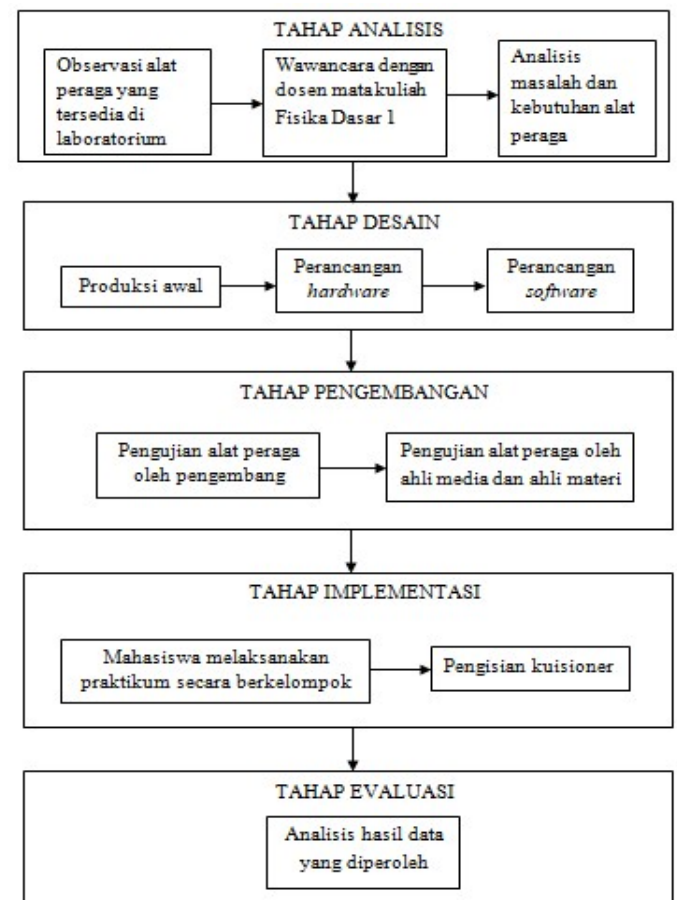

Gambar 1. Bagan Prosedur Penelitian

Teknik pengumpulan data yang dilakukan yaitu studi analisis kebutuhan yang dilakukan oleh mahasiswa untuk memperoleh data dan informasi bahwa alat peraga gerak lurus dengan linear air track berbasis Arduino Uno dibutuhkan. Selanjutnya yaitu metode dokumentasi yang dilakukan selama proses penelitian berlangsung. Metode angket digunakan untuk mengetahui respon mahasiswa terhadap alat peraga gerak lurus yang dikembangkan. Lembar keterlaksanaan pembelajaran digunakan untuk mengetahui uji kepraktisan alat peraga. Teknik pengumpulan data selanjutnya yaitu validasi ahli media dan ahli materi. Sebelum alat peraga diimplementasikan kepada mahasiswa, alat peraga divalidasi dengan menggunkan lembar validasi media lembar validasi ini ditujukan kepada dosen ahli media, sedangkan validasi ahli materi dilakukan untuk memvalidasi keterkaitan alat peraga dengan materi gerak lurus menggunakan lembar validasi materi.

Teknik analisis data yang digunakan yaitu analisis uji coba alat, analisis ini digunakan untuk menguji kinerja alat dengan membandingkan hasil pengambilan data dengan manual dan pengambilan data dengan menggunakan sensor infrared. Selanjutnya yaitu analisis data instrumen validasi 
alat, analisis ini dilakukan oleh ahli media dan ahli materi menggunakan rating scale. Instrumen ini diberikan empat kategori pilihan jawaban dan skor dengan ketentuan: skor 4 (sangat baik), 3 (baik), 2 (kurang baik), dan 1 (tidak baik).

\section{HASIL DAN PEMBAHASAN}

\section{A. Analysis (Analisis)}

Berdasarkan analisis kebutuhan mahasiswa melalui lembar studi analisis serta wawancara dengan dosen Fisika Dasar 1 diperoleh informasi bahwa alat peraga yang terdapat di laboratorium universitas muhammadiyah purworejo belum menggunakan basis digital khususnya alat peraga gerak lurus. Alat peraga gerak lurus masih menggunakan ticker timer dan stopwatch manual untuk menghitung troli saat melaju sehingga mahasiswa harus benar-benar cermat dalam pengabilan data untuk mendapatkan hasil yang akurat. Selain itu terdapat beberapa mahasiswa yang kurang aktif dan antusias dalam mengikuti proses pembelajaran. Proses pembelajaran biasanya menggunakan media persentasi, tugasdan media peraga sederhana hal tersebut dikarenakan karena keterbatasan alat yang ada. Mahasiswa merasa senang dan mudah memahami materi jika perkulihan Fisika Dasar 1 menggunakan sumber belajar yang inovatif serta dengan media alat peraga yang dapat menunjukkan cara kerja dan menunjukkan materi dengan detail oleh karena itu peneliti perlu mengembangkan alat peraga gerak lurus dengan linear ai track berbasis Arduino Uno.

\section{B. Design (Desain)}

Tahap perancangan meliputi perancangan body alat dan perancangan keseluruhan system yang meliputiprogram dan body alat. Pembuatan program digunakan untuk mengaktifkan sensor infrared sebagai pengukur waktu pada percobaan gerak lurus secara otomatis. Pembuatan body alat dilakukan beriringan dengan perancangan program. Desain alat dapat dilihat pada Gambar 2.

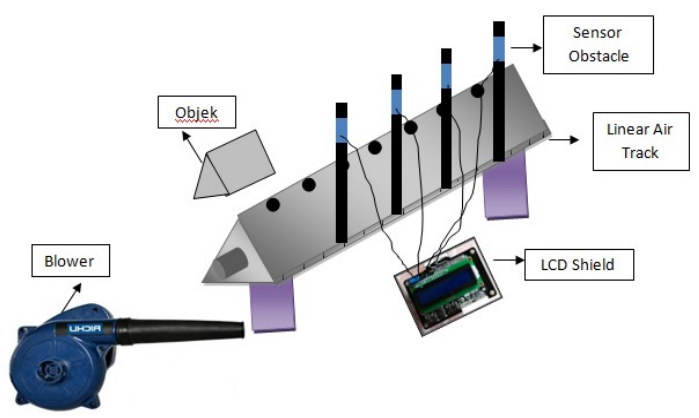

Gambar 2. Desain Alat Peraga Gerak Lurus

\section{Development (Pengembangan)}

1. Pengujian Alat

a. Uji Sensor Infrared

Pengujian sensor infrared ini dilakukan sebanyak lima kali percobaan pada masing-masing item sensor infrared. Setelah melakukan uji sensor diperoleh data yang cukup presisi. Sensor infrared satu dengan yang lainnyapun tidak jauh berbeda, hanya selisih $0,01 \mathrm{~V}$. Hal ini disebabkan karena setiap sensor tingkat sensitivitasnya tidak selalu sama dan kalaupun berbeda hanya memiliki nilai perbedaan yang sangat kecil. Diagram hasil uji sensor infrared disajikan pada Gambar 3.

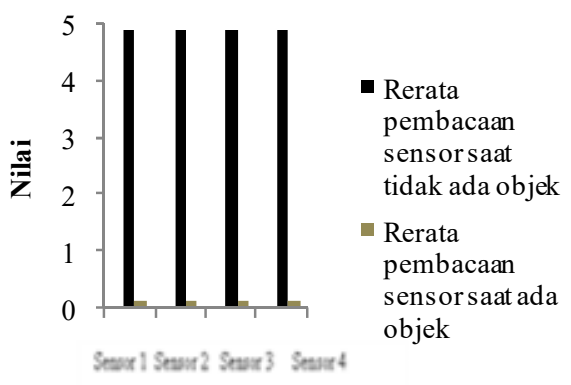

Gambar 3. Diagram Hasil Uji Sensor Infrared

b. Uji Pembacaan Sensor Infrared

Pengujian pembacaan sensor infrared yang dibandingkan dengan stopwatch diperoleh kesalahan pengukuran sebesar $2,255 \%$. Grafik hubungan pengukuran sensor dengan stopwatch disajikan pada Gambar 4.

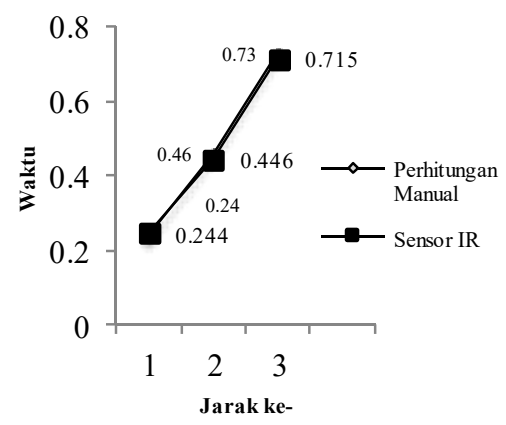

Gambar 4. Grafik Hubungan Pengukuran Sensor dengan Stopwatch

c. Uji Sistem

Uji sistem ini dilakukan sebanyak sepuluh kali percobaan. Hasil 
pengukuran pada alat peraga gerak lurus dengan linear air track berbasis Arduino pada jarak $0,1 \mathrm{~m}$ diperoleh ralat waktu percobaan senilai pada

jarak 0,2 m senilai $(0,2420 \pm 0,2003) x$

$$
\text { pada jarak } 0,3 \mathrm{~m}\left(\begin{array}{c}
(0,4580 \pm 0,0008) \\
0,7150 \pm 0,0095)
\end{array}\right.
$$

dari hasil penghitungan manual yaitu, pada jarak $0,1 \mathrm{~m}$ senilai , jarak

$$
(0,2400+0,0004)
$$

$0,2 \mathrm{~m}$ senilai , dan pada

jarak $0,3 \mathrm{~m}$ senilai

$$
(0,4600 \pm 0,0011)
$$

$(0,7300 \pm 0,0085)$

Grafik perbandinagn data hasil perhitungan waktu menggunakan alat peraga gerak lurus dengan linear air track berbasis Aduino uno dengan hasil perhitungan manual disajikan pada Gambar 4.

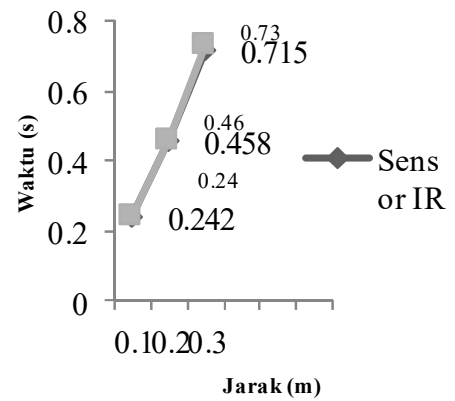

Gambar 4. Grafik Perbandingans Terhadap $t$ Hasil Pengambilan Data Alat Peraga Gerak Lurus dengan Linear Air Track Berbasis Arduino Uno dengan Manual

Setelah diperoleh data waktu pada percobaan gerak lurus dengan menggunakan linear air track berbasis Arduino Uno dan dengan manual maka diperoleh hasil penghitungan kecepatan. Grafik perbandinagn hasil penghitungan kecepatan pada percobaan gerak lurus dengan linear air track berbasis Arduino Uno dan perhitungan manual disajikan pada Gambar 6.

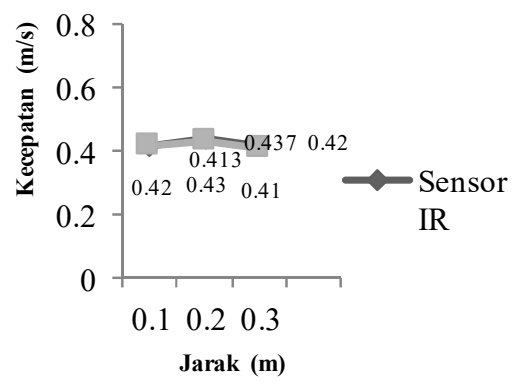

Gambar 6. Grafik $v$ Terhadap $t$ Hasil Pengambilan data Alat Peraga Gerak Lurus dengan Linear Air Track Berbasis Arduino Uno dan Perhitungan Manual

2. Validasi Alat

a. Data Hasil Validasi Ahli Media

Hasil validasi oleh ahli mediadiperoleh rerata skor pada aspek ketahanan alat sebesar 84,5 \%, keakuratan alat 93,5\%, efisiensi alat $79,25 \%$, estetika $75 \%$, keamanan $81,25 \%$ dan kotak KIT 87,5\%, sedangkan untuk buku panduan pada aspek teknis mendapatkan nilai $72 \%$ dan kelayakan bahasa sebesar 79\%. Dari hasil tersebut diperoleh nilai persentase rata-rata yaitu $86,33 \%$ (kategori sangat baik).

b. Validasi Ahli Materi

Persentase hasil validasi alat peraga gerak lurus dengan linear air track berbasis Arduino Uno oleh ahli materi pada aspek keterkaitan dengan materi bahan ajar senilai $81,25 \%$, nilai pendidikan $81,25 \%$, efisiensi alat $75 \%$, sedangkan untuk buku panduan pada aspek kelayakan isi mendapatkan $71 \%$, kelayakan penyajian $66,5 \%$, dan kelayakan bahasa $78 \%$. Dari hasil tersebut diperoleh rata-rata persentase kelayakan alat peraga dan buku panduan sebesar 75,5\% dengan kategori baik.

c. Hasil Uji Reliabilitas

Hasil uji reliabilitas yang diperoleh pada aspek keterkaitan bahan ajar mendapatkan nilai reliabilitas senilai $77 \%$, nilai pendidikan $92 \%$, efisiensi alat $84 \%$, ketahanan alat $96 \%$, keakuratan alat $90 \%$, estetika $100 \%$, keamanan $92 \%$, kotak KIT $86 \%$, teknis $78 \%$, kelayakan isi $71 \%$, kelayakan penyajian $75 \%$ dan kelayakan bahasa $95 \%$, sehingga rata-rata akhir yang diperoleh adalah $86,33 \%$ dengan kategori sangat reliabel. 
D. Implementation (Penerapan)

1. Keterlaksanaan Pembelajaran

Hasil yang diperoleh daridua observer pada aspek pendahuluan memperoleh jumlah skor senilai 16,00 dengan persentase senilai $100 \%$, kegiatan inti memperoleh jumlah skor 26,00 dengan persentase $81 \%$, dan penutup memperoleh jumlah skor senilai 16,00 dengan persentase senilai $100 \%$, dari hasil tersebut diperoleh rerata skor senilai 3,75 dengan persentase $93,7 \%$ memiliki kategori sangat baik.

\section{Respon Mahasiswa}

Hasil persentase yang diperoleh berdasarkan respon mahasiswa pada aspek manfaat memperoleh $88,6 \%$, pada aspek penyajian alat memperoleh persentase senilai $85,2 \%$ dan pada aspek penampilan fisik memperoleh persentase senilai $83,2 \%$. Rerata keseluruhan dari ketiga aspek tersebut senilai $85,67 \%$ dengan kategori baik. Data hasil respon mahasiswa disajikan pada Tabel 5 .

Tabel 5. Data Hasil Respon Mahasiswa

\begin{tabular}{|c|c|c|c|}
\hline No & Aspek yang Dinilai & Skor & Persentase $(\%)$ \\
\hline 1 & Manfaat & 14,18 & 88,6 \\
\hline 2 & Penyajian Alat & 20,45 & 85,2 \\
\hline 3 & Penampilan Fisik & 16,64 & 83,2 \\
\hline & Jumlah & 51,27 & 257 \\
\hline & Rerata & 17,09 & 85,67 \\
\hline \multicolumn{3}{|c|}{ Kategori } & Baik \\
\hline
\end{tabular}

\section{E. Evaluation (Evaluasi)}

Berdasarkan data di atas, maka alat peragagerak lurus dengan linear air track berbasis Arduino Uno dapat digunakan sebagai media pembelajaran pada materi Fisika Dasar 1 khususnya pada pokok bahasan gerak lurus. Rerata persentase hasil perolehan dari validasi ahli media senilai 80,25\% dengan kategori sangat baik dan perolehan rerata skor oleh validasi ahli materi yaitu $75,5 \%$ dengan kategori baik sedangkan perolehan rerata persentase perolehan dari respon mahasiswa yaitu $85,67 \%$ dengan kategori baik dan respon mahasiswa setelah menggunakan alat peraga perolehan rata-rata skor senilai 17,09 dengan persentase 85,67 termasuk kategori baik.

Evaluasi yang dilakukan yaitu dengan memperbaiki beberapa bagian dari produk yang dihasilkan berdasarkan saran dan masukan oleh validatordan masukan dari mahasiswa pada saat melakukan pembelajaran menggunakan alat peraga gerak lurus dengan linear air track berbasis Arduino.

Berdasarkan hasil yang diperoleh pada uji sensor infraredyang dilakukan dengan menginput program khusus untuk pembaacaan sensor infraredakan memperoleh output jika sensor infrared tidak diberi penghalang (objek) nilainya 5 dan apabila sensor infrared diberi penghalang (objek) nilainya 0 . Hasil pembacaan sensor infrared ditampilkan melalui serial monitor pada laptop. Uji sensor infrared dilkukan sebanyak 5 kali pada masing-masing sensor yang semuanya berjumlah 4 sensor. Data yang diperoleh sensor infrared pada Gambar 3 menunjukkan bahwa sensor bekerja dengan baik serta hasil yang diperoleh cukup presisi. Sensor 1 dengan yang lainnya mengalami perbedaan nilai selisih sebesar $0,01 \quad V$ hal tersebut dikarenakan tingkat sensitivitas sensor 1 dengan sensor yang lain berbeda.

Pengujian selanjutnya yaitu uji kalibrasi yang bertujuan untuk mengetahui tingkat akurasi sensor. Pengujian dilakukan sebanyak 10 kali percobaan dengan membandingkan percobaan menggunakan alat peraga berbasis Arduino dan secara manual. Selisih nilai yang diperoleh pada uji kalibrasi ini adalah 0,008 $s$. sensor ini bekerja secara baik dibuktikan dengan persentase kesalahan 2,255 \%. Penelitian ini sejalan dengan penelitian sebelumnya tentang Pengembangan KIT Optik Berbasis Sensor Infrared untuk Peserta Didik SMA [11]. Data hasil perbandingan uji kalibrasi sensor infrared dengan manual memiliki kesalahan yang diakibatkan karena saat menekan tombol stopwatch tidak dapat bersamaan dengan kerja sensor, kurangnya kevermatan dalam pengambilan data manual dan tingkat ketelitian antara stopwatch dengan sensor berbeda. Data pengamatan lebih teliti dari hasil penghitungan menggunakan alat berbasis Arduino.

Setelah dilakukan uji kalibrasi kemudian peneliti melakukan uji alat peraga secara keseluruhan untuk mengetahui kesalahan relatifnya. Percobaan ini dilakukan sebanyak 10 kali.Grafik prbandingan nilai $s$ terhadap $t$ pada percobaan gerak lurus dengan linear air track berbasis Arduino Uno dan percobaan gerak lurus dengan perhitungan manual dapat dilihat pada Gambar 5, pada grafik tersebut menunjukkan bahwa semakin lama selang waktu tempuh semakin panjang pula jarak lintasan benda yang dilaluinya. Hasil percobaan menggunakan sensor dan secara manualpun sejalan, hanya memiliki selisih sangat kecil. Grafik perbandingan $v$ terhadap $t$ pada percobaan gerak lurus dengan linear air track berbasis Arduino Uno dan percobaan gerak lurus dengan perhitungan manual dapat dilihat pada Gambar 6, hal tersebut membuktikan bahwa benda luncur melaju dengan kecepatan konstan. Berdasarkan hasil percobaan yang dilakukan pada lintasan ke-tiga nilai ralat peling besar, hal ini dikarenakan panjang lintasannya paling jauh sehingga hambatan benda luncur saat melintaspun semakin banyak karena terdapat sedikit gesekan antara lubang linear air 
track dengan benda luncurnya sehingga menyebabkan benda luncur tidak stabil saat melintas melewati sensor. Hasil penelitian tersebut relevan dengan penelitian yang dilakukan sebelumnya tentang Pengembangan Alat Peraga Ticker Timer sebagai Media Pembelajaran Fisika Pokok Bahasan Gerak Lurus [12].

Berdasarkan hasil validasi ahli media pada aspek kotak KIT memperoleh skor tertinggi karena alat peraga didesain dengan sedemkian rupa sehingga walaupun terlihat besar namun mudah dibawa dan praktis serta dilengkapi dengan box sehingga alat peraga terlihat rapi. Sedangkan pada aspek estetika alat peraga memperoleh skor paling rendah karena warna alat peraga kurang menarik dan lubang air track masih terdapat plaster sebagai pengecil lubang. Berdasarkan penilaian validasi ahli materi terhadap buku panduan cukup rendah karena pada buku panduan alat belum tercantum materi tentang gerak lurus serta gambar alat peraga gerak lurus dengan air trackkurang detail. Rerata dari dosen ahli media dan ahli materi adalah 3,14, uji reliabilitas menunjukkan $86,33 \%$ dan dinyatakan sangat reliabel. Data perolehan dari dosen ahli dapat dikatakan valid, hal tersebut sejalan dengan penelitian yang dilakukan sebelumnya tentang Pengembangan Alat Pengukur Energi Mekanik pada Pokok Bahasan Usaha dan Energi Berbasis Mikrokotroler Arduino Uno untuk Meningkatkan Aspek Psikomotorik Siswa.

Hasil respon siswa terhadap alat peraga pada aspek manfaat mendapat persentase paling tinggi yaitu $88,6 \%$ hal tersebut dikarenakan alat peraga sesuai dengan kebutuhan mahasiswa dan alat peraga sesuai dengan konsep fisika yang diajarkan. Sedangkan hasil keterlaksanaan pembelajaran nilai persentase paling rendah yaitu pada kegiatan inti, karena pada saat kegiatan pembelajaran menggunakan alat peraga air trackterdapat beberapa hambatan, diantaranya benda luncur harus diberi sedikit dorongan terlebih dahulu agar bergerak melewati sensor dan antara benda luncur dengan air track terdapat sedikit gesekan sehingga menyebabkan benda luncur tidak stabil dan mahasiswa harus melakukan percobaan ulang untuk memperoleh data yang lebih baik. Rerata dari 3 aspek keterlaksanaan pembelajan yang meliputi aspek pendahuluan, kegiatan inti dan penutup memperoleh rerata persentase 93,7\% dengan kategori sangat baik. Hasil perolehan data respon dan keterlaksanaan pembelajaran ini sejalan dengan penelitian terdahulu tentang Pengembangan Alat Peraga IPA Terpadu pada Tema Pemisahan Campuran untuk Meningkatkan Keterampilan Proses Sains [13].

\section{KESIMPULAN}

Penelitian yang dilakukandengan menggunakan model pengembangan ADDIE (Analysis Design Develop Implementation Evaluation)telah menghasilkan media pembelajaran berupa alat peraga gerak lurus dengan linear air track berbasis Arduino Uno untuk menghitung waktu benda melintas di atas linear air track yang diberi tekanaan udara dari blower.

Pengembangan alat peraga gerak lurus ini memiliki tingkat akurasi dan tingkat validitas yang baik serta alat peraga gerak lurus dengan linear air track berbasis Arduino Uno ini praktis digunakan dalam pembelajaran.

\section{DAFTAR PUSTAKA}

[1] Mananda, Irma. 2017. "Penggunaan Media Pembelajaran Macromedia Flash Untuk Meningkatkan Pemahaman Konsep Siswa Pada Pokok Bahasan Hukum Newton." Jurnal Ilmiah Mahasiswa FKIP Prodi FISIKA 1(1).

[2] Kause, Migdes C. 2019. "Rancang Bangun Alat Peraga Fisika Berbasis Arduino (Studi Kasus Gerak Jatuh Bebas)." CYCLOTRON: JURNAL TEKNIK ELEKTRO 2(1).

[3] Satria, Erwinsyah, and Syafni Gustina Sari. 2018. "Penggunaan Alat Peraga Dan KIT IPA Oleh Guru Dalam Pembelajaran Di Beberapa Sekolah Dasar Di Kecamatan Padang Utara Dan Nanggalo Kota Padang." IKRA-ITH HUMANIORA: Jurnal Sosial dan Humaniora 2(2): 1-8.

[4] Jalil, Restu Maharani. 2016. "Kelayakan Media Alat Peraga Air Mancur Sederhana Untuk Meningkatkan Pemahaman Konsep Pada Materi Hukum Boyle." Pensa: Jurnal Pendidikan Sains 4(03).

[5] [Maharani, Meyrika, Mustika Wati, and Sri Hartini. 2017. "Pengembangan Peraga Pada Materi Usaha Dan Energi Untuk Melatihkan Keterampilan Proses Sains Melalui Model Iquiry Discovery Learning (IDL Terbimbing)." Berkala Ilmiah Pendidikan Fisika 5(3): 351-67.

[6] Syarifah, Wihdatus, and Arik Pujiyanti. 2020. "Development of Centripetal Acceleration Practicum Based on Arduino Nano and Infrared Sensors with Dimmer Switch." In International Conference on Science and Education and Technology (ISET 2019), Atlantis Press, 55153.

[7] Rochayati, Umi, and Suprapto Suprapto. 2014. "Kefektifan Trainer Digital Berbasis Mikrokontroler Dengan Model Briefcase Dalam Pembelajaran Praktik Di Smk." Jurnal Kependidikan: Penelitian Inovasi Pembelajaran 44(2). 
[8] Musik, Panjit. 2017. "Development of Computer-Based Experiment Set on Simple Harmonic Motion of Mass on Springs." Turkish Online Journal of Educational TechnologyTOJET 16(4): 1-11.

[9] Triaga, Even, Yulkifli Yulkifli, and Yohandri Yohandri. 2017. "Pembuatan Air Track Untuk Eksperimen Kinematika Dan Dinamika Berbasis Mikrokontroler Atmega328." PILLAR OF PHYSICS 10(1).

[10] Pribadi, Benny A. 2016. Desain Dan Pengembangan Program Pelatihan Berbasis Kompetensi Implementasi Model ADDIE. Kencana.

[11] Rohmansyah, Inggit, and Abd Kholiq. "Pengembangan KIT Optik Berbasis Sensor Infrared Untuk Peserta Didik SMA."

[12] Sobari, Achmad. 2016. "Pengembangan Alat Peraga Ticker Timer Sebagai Media Pembelajaran Fisika Pokok Bahasan Gerak Lurus.” Inovasi Pendidikan Fisika 5(3).

[13] Apriliyanti, D.D., Sari, H., \& Widiyatmoko. A. 2015. "Pengembangan Alat Peraga IPA Terpadu Pada Tema Pemisahan Campuran Untuk Meningkatkan Keterampilan Proses Sains." Unnes Science Education Journal. 